\title{
African Indigenous Medicine Activities in Mbarara Municipality, Uganda
}

\author{
Dr. Barigye Godfrey (Phd-Is, Mapam, Ba, Des,Cal) \\ Kabale University P.O. Box 317 Kabale, Uganda
}

*Corresponding Author: Dr. Barigye Godfrey, Kabale University P.O. Box 317 Kabale, Uganda

\begin{abstract}
Some African indigenous medicine healers and neo-liberalists have misused the cherished objectives of community values and turned it into witch-craft characterized with human sacrifice, money extortion, and many more evil related practices. The study was on activities of traditional indigenous knowledge in Mbarara Municipality, Uganda. It was established that most African indigenous healers were mainly practicing herbalism, midwifery/traditional birth attendance, spirituality/foretelling, bone-setters, snake poison healers and rain-makers. The African indigenous healers were in the age group of 40 years and above, had an educational level of secondary, most of them were females, who were Banyankore, Baganda, Congolese and Swahili, and were married. Most of the beneficiaries of African indigenous medicine were farmers and Banyankore by tribe. It was concluded that African indigenous medicine practices and systems of local people are interactive technology whose dissemination is feasible, efficient, and cost-effective when learnt from village-level experts.
\end{abstract}

Keywords: African Indigenous Knowledge

\section{INTRODUCTION}

African indigenous medicine ((AIM) and healing knowledge (HK) involve medicinal and spirituality activities. The new generation of peri-urban dwellers in Mbarara Municipality use modern medicine competitively with African indigenous medicine.

According to the National Council of Traditional Healers and Herbalists Associations of Uganda (NCTHHA), African indigenous medicine refers to 'ways of protecting and restoring health that existed before the arrival of modern medicine with medicinal plants being the world's oldest known health-care products'. AIM is perceived to be more 'natural and safer' than conventional therapies and is an important and often underestimated part of prevention and treatment health services. AIM, of proven quality, safety, and efficacy, contribute to the goals of ensuring that all people have access to care. is care that is close to their homes, accessible and affordable. It is also culturally acceptable and trusted by large numbers of people. The affordability of most AIM makes them all the more attractive at a time of soaring health-care costs and nearly universal austerity. AIM also stands out as a way of coping with relentless rise of chronic non-communicable diseases. It should however be noted that in spite of the importance of AIM to the health of the people, it raises questions of safety and quality. There are reports that quack African indigenous healers have taken advantage of desperate and hapless patients. Consequently, there is an urge to develop legal and policy frameworks to regulate the activities of indigenous African medical practices.

\section{AFriCAN IndigenOUS MEdicine In Mbarara MuniCiPALITY}

African indigenous medicine and healing knowledge in Uganda as in many parts of Africa is a holistic conception that places the individual in relation to other men, to nature and to the Universe (Sekagya, 2006). Sickness is seen as an imbalance caused by lack of harmony or offending universal laws and not as a result of physiological or biological malfunctioning: an imbalanced state opens the individual to vulnerable influences. Ovugaet al., (1999) asserts that mental illnesses are caused by evil spirits, witchcraft or curses. Therefore connecting with the spirits is important to help patients and families: the rituals to connect consist of song, drumming, clapping, dancing and a variety of performances to bring the spirit strongly into the midst of people. When the spirits are recognized for what they are and are respected, they stop acting harmful and start to bring help and support (Turner, 2004; 
Scheidegger and Degonda, 2008). If connecting is not the way to restore somebody's health a variety of shamanistic procedures can be used: exercises, diet, herbs, relaxation, mental im6aginary, surgery, prayers, purifications, and various other rituals.

The study considered the health training of the leaders in order to investigate whether these leaders had the knowledge about conventional and indigenous African medicinal healing knowledge with community development dynamics (Table 1.2, below). Of the 27 sampled leaders, 17 respondents said they had some training on health matters and had the ability to explain issues that regard health matters in both modern and indigenous African healing perspectives. The findings from the study showed that even the 17 respondents who trained in health issues, $76.5 \%$ had modern health training skills (primary health care) and $23.5 \%$ had African indigenous medicine and healing knowledge (birth attendance only). Even the $23.5 \%$ was enough to show that even some of the leaders were practitioners of African indigenous medicine and healing knowledge: this affirmed the existence and importance of African medicine in Mbarara Municipality.

Table 1.1: Health training of Leaders in Mbarara Municipality

\begin{tabular}{|l|c|c}
\hline Health Training & Frequency & Percentage \\
\hline Modern & 13 & 76.5 \\
\hline African Indigenous medicine & 04 & 23.5 \\
\hline Total & $\mathbf{1 7}$ & $\mathbf{1 0 0}$ \\
\hline
\end{tabular}

Source: Leaders (Field data, 2015)

\subsection{Response from National Cultural Herbalists and Healers Associations}

To have a more in-depth investigation, the study involved committees of National Cultural Traditional Herbalists and Healers Association (NCTHHA) and were interviewed separately. It was established that each Municipal Division in Mbarara Municipality has a five-member committee of NCTTHA elected from African indigenous healers (IAHs) that composed of traditional birth attendants, spiritualists, bone-setters, rain-makers, herbalists and foretellers. The study considered six committees (30 respondents in total) but was able to interface with 26 members from the Municipal Divisions of Biharwe, Kakiika, Kakoba, Kamukuzi, Nyakayojo and Nyamatanga. It was found out that the members of NCTHHA were drawn from spiritualists/foretellers, birth attendants, herbalists, rainmakers and bone-setters.

Table 1.2 below shows the membership and nationality of National Cultural Traditional Herbalists and Health Associations by numbers and percentages respectively.

\begin{tabular}{|c|c|c|c|c|c|c|c|c|c|c|c|c|c|}
\hline \multirow[t]{3}{*}{ Membership } & \multirow[b]{3}{*}{ Frea } & \multirow[b]{3}{*}{$\%$} & \multicolumn{10}{|c|}{ Nationality } & \multirow{3}{*}{$\begin{array}{l}\text { Total } \\
\mathrm{N}\end{array}$} \\
\hline & & & \multicolumn{2}{|c|}{ Congolese } & \multicolumn{2}{|c|}{ Kenyan } & \multicolumn{2}{|c|}{ Rwandan } & \multicolumn{2}{|c|}{ Ugandan } & \multicolumn{2}{|c|}{ Tanzanian } & \\
\hline & & & freq & $\%$ & frea & $\%$ & frea & $\%$ & freq & $\%$ & freq & $\%$ & \\
\hline Spiritualists & 12 & 46.2 & 01 & 8.3 & 01 & 8.3 & 01 & 8.3 & 07 & 58.3 & 02 & 16.7 & 12 \\
\hline TBAs & 05 & 19.3 & 00 & $O O$ & 00 & $O O$ & OO & $O O$ & 02 & 66.7 & 01 & 33.3 & 03 \\
\hline Herbalists & 04 & 15.4 & 00 & $O O$ & 01 & 50 & 00 & $O O$ & 01 & 50 & 00 & $O O$ & 02 \\
\hline Foretellers & 03 & 11.5 & 00 & $O O$ & 00 & $O O$ & 00 & $O O$ & 03 & 700 & 00 & $O O$ & 03 \\
\hline Bonesetters & 01 & 3.8 & 00 & $O O$ & 00 & $O O$ & 00 & $O O$ & 01 & 100 & 00 & $O O$ & 01 \\
\hline Rainmakers & 01 & 3.8 & 00 & $O O$ & 00 & $O O$ & 00 & $O O$ & 01 & 700 & $\mathrm{OO}$ & $O O$ & 01 \\
\hline Total & 26 & 100 & 01 & 4.5 & 02 & 9.1 & 01 & 4.5 & 15 & 68.2 & 3 & 13.6 & 22 \\
\hline No response & 04 & 13.3 & & & & & & & & & & & 08 \\
\hline
\end{tabular}

Further investigation on NCTHHA committees' members showed that they had different nationalities (as shown in Table 1.2 above): Ugandans, Congolese, Kenyans and Tanzanians. Notably, the Congolese and Rwandans had only spiritualists, Kenyans had herbalists and spiritualists, Tanzanians had spiritualists and traditional birth attendants (TBAs), while Ugandans had all categories (TBAs, spiritualists, herbalists, foretellers, bonesetters, rain makers). During the field work, some members of the NCTHHA committees refused to mention their tribes and even nationalities and insisted to be called Africans (only 22 members responded). They said that African have no differences and thus words like language, tribe and nationality were labels by foreigners (Whites and Arabs). Various reasons were given as to support the African indigenous medicine and healing knowledge by these NCTHHA committees and they said: 
“....African traditional healers who practice spirituality have their powerful knowledge derived from spirits of the lakes, rivers, mountains and the sky...their forefathers have a connection in providing the super natural powers to the healers... the dead are living with us and heal our diseases......" Source: Field Interview: November, 2015.

The study further investigated the relationship between age and sex of the NCTHHA committees' members, community development and African indigenous medicine and healing knowledge in Mbarara Municipality as shown in Table 1.3 below.

\begin{tabular}{|c|c|c|c|c|c|c|c|c|c|c|c|c|}
\hline \multirow[t]{3}{*}{ Membership } & \multicolumn{6}{|c|}{ Age (Years) } & Total & \multicolumn{4}{|c|}{ Sex } & \multirow{3}{*}{$\begin{array}{c}\text { Total } \\
n\end{array}$} \\
\hline & \multicolumn{2}{|c|}{ 30-39 } & \multicolumn{2}{|c|}{$40-49$} & \multicolumn{2}{|c|}{$50-60+$} & \multirow[b]{2}{*}{$\boldsymbol{N}$} & \multicolumn{2}{|c|}{ Male } & \multicolumn{2}{|c|}{ Female } & \\
\hline & freq & $\%$ & freq & $\%$ & freq & $\%$ & & freq & $\%$ & freq & $\%$ & \\
\hline Spiritualists & 02 & 16.7 & 03 & 25 & 07 & 58.3 & 12 & 08 & 66.7 & 04 & 33.3 & 12 \\
\hline TBA & 00 & $O O$ & 01 & 33.3 & 02 & 66.7 & 03 & 02 & 40 & 03 & 60 & 05 \\
\hline Herbalists & 01 & 25 & 01 & 25 & 02 & 50 & 04 & 02 & 50 & 02 & 50 & 04 \\
\hline Foretellers & $\mathrm{OO}$ & $O O$ & 00 & $O O$ & 03 & 100 & 03 & 01 & 33.3 & 02 & 66.7 & 03 \\
\hline Bonesetters & $\mathrm{OO}$ & $O O$ & 00 & $O O$ & 01 & 100 & 01 & 01 & 100 & OO & $O O$ & 01 \\
\hline Rain makers & $\mathrm{OO}$ & $O O$ & $\mathrm{OO}$ & $O O$ & $\mathrm{OO}$ & $O O$ & $O O$ & 01 & 100 & $\mathrm{OO}$ & $O O$ & 01 \\
\hline Total & 03 & 13 & 05 & 21.7 & 15 & 65.2 & 23 & 15 & 57.7 & 11 & 42.3 & 26 \\
\hline No response & & & & & & & 07 & & & & & 04 \\
\hline
\end{tabular}

The findings show that the majority of the NCTHHA were 50 years and above consisting 15 respondents $(65.2 \%)$. There were only three committee members that were in the youthful age (30-39 years who represented $13 \%$ and five members that were between $40-49$ years $(21.7 \%)$. To a more surprise the two youthful healers were spiritualists, females and had attended University formal education and single. When interviewed they said that they were 'dem-gods' and had their spiritual powers from abacwezi. Indigenous African female healers provide an important link between rural people and primary health care: older African women healers particularly play such roles. But findings from the field showed that these young spiritualists also existed and the training of indigenous African women in medicine and healing knowledge requires further consideration and plan for implementation (Nelms and Gorski, 2006).

The age cohorts of NCTHHA showed that these respondents were mature and the data sought from them were affirmative of their response in relation to causes of African indigenous medicine and healing knowledge in Mbarara Municipality. It was found out that the majority of NCTHHA committees were spiritualists: $30.4 \%$ as shown in Table 1.3. It was found out that sex of the NCTHHA committee members was mainly males (57.7\%) but this did not necessarily confirm that the majority of African indigenous healers in Mbarara Municipality were males. The majority of males in NCTHHAs could be due to election procedures to those committees, however this affirmed that neo-liberalistic and capitalism from the Western politics have entered the governance of African indigenous medicine and healing knowledge practices.

An investigation using a cross-tabulation was done on NCTHHA committees' members to establish their education levels and marital status as indicated in Table 1.4 below.

Table 1.4: Educational levels and Marital Status of NCTHHA in Mbarara Municipality

\begin{tabular}{|c|c|c|c|c|c|c|c|c|c|c|c|c|c|c|}
\hline \multirow{3}{*}{$\begin{array}{l}\text { Membership } \\
\text { Response }\end{array}$} & \multicolumn{8}{|c|}{ Educational Levels } & \multicolumn{6}{|c|}{ Sex } \\
\hline & \multicolumn{2}{|c|}{$\begin{array}{c}\text { University/ } \\
\text { Tertiary }\end{array}$} & \multicolumn{2}{|c|}{ Secondary } & \multicolumn{2}{|c|}{ Primary } & \multicolumn{2}{|c|}{$\begin{array}{l}\text { Informal } \\
\text { education }\end{array}$} & \multicolumn{2}{|c|}{ Married } & \multicolumn{2}{|c|}{ Single } & \multicolumn{2}{|c|}{$\begin{array}{l}\text { Widow/ } \\
\text { Widower }\end{array}$} \\
\hline & freq & $\%$ & freq & $\%$ & freq & $\%$ & Freq & $\%$ & freq & $\%$ & freg & $\%$ & freq & $\%$ \\
\hline Spiritualists & 02 & 16.6 & 02 & 16.6 & 01 & 8.3 & 07 & 58.3 & 07 & 70 & 02 & 20 & 01 & 10 \\
\hline TBA & 00 & 00 & 01 & 20 & 02 & 40 & 02 & 40 & 05 & 71.4 & 02 & 28.6 & 00 & 00 \\
\hline Herbalists & 00 & 00 & 03 & 75 & 01 & 25 & 00 & 00 & 01 & 25 & 03 & 75 & 00 & 00 \\
\hline Foretellers & 00 & 00 & 00 & 00 & 00 & 00 & 03 & 100 & 01 & 33.3 & 00 & 00 & 02 & 66.7 \\
\hline Bonesetters & 00 & 00 & 01 & 100 & 00 & 00 & 00 & 00 & 00 & 00 & 00 & 00 & 01 & 100 \\
\hline Rain makers & 00 & 00 & 00 & 00 & 01 & 100 & 00 & 00 & 00 & 00 & 01 & 100 & 00 & 00 \\
\hline Total & 02 & 7.7 & 7 & 26.9 & 5 & 19.2 & 12 & 46.2 & 14 & 53.8 & 08 & 30.8 & 04 & 15.4 \\
\hline
\end{tabular}


It was found out that most NCTTHA committee members were formally educated $(53.8 \%)$ : University education had $7.7 \%$, Secondary education was $26.9 \%$ and $19.2 \%$ had at least formal primary education. Two members who practiced spirituality had attained university education and on further inquiry on why this was so, these two respondents said they had inherited the African indigenous medicine knowledge of spirituality from their parents and never trained by any person or institution. It was established that those with informal education (46.2\%) were traditional birth attendants (who used indigenous knowledge), spiritualists (powers to connect with ancestors and other super natural powers in the sky, under the water and in the wilderness) and the foretellers. Awofeso (2005) argues that in African indigenous medicine and health care delivery includes curative, apprenticeship (training), promotional and rehabilitation services. These services are being provided through tradition and cultural philosophy for example "Ubuntu" philosophy and do not need formal education but the philosophy requires a traditional healers to provide health services under a "humanity first" consideration and not for material gain.

Most NCTTHA committee' members were married (53.8\%), singles were eight respondents (30.8\%) and the widow/widower was four $(15.4 \%)$. Further investigation showed that most herbalists $(75 \%)$ were singles, followed by TBAs (71.4\%), spiritualist 7(70\%) and foretellers (66.7\%). It was also established from the interviews held with the singles that they were among those with high education levels [university and secondary level (33.2\%)]. The reasons of these highly educated singles engaging in African indigenous medicine and healing activities included lack of unemployment by the youth that makes them engage in whatever income generating activity that are available. They argued that herbalism or general traditional healing practices were a lucrative business for them. However, Awofeso (2005), describe a traditional healer as a person of high standing in a community, open and available to serve others, when they need health care services but no one is interested in commercializing African medicine and healing knowledge.

The study investigated the health training of NCTHHA committee members to verify whether they had knowledge about African indigenous medicine and healing knowledge. It was found out that only $15.4 \%$ of the committee members had training in modern medicine, while $84.6 \%$ had only traditional health skills and six members were silent: this response strongly affirmed their knowledge-ability in African indigenous healing knowledge based on inherited knowledge and skills from ancestors.

\subsection{Responses of African Indigenous Healers (AITHs)}

The study involved African Indigenous healers in Mbarara Municipality to get their views on community development and African indigenous medicine and healing knowledge. It was found out that there were various categories of African indigenous healers (bone-setters, snake poison healers, witch-doctors, herbalists, spiritualists, rain-makers and traditional birth attendants).

The study used interviews and group discussion for a sample size of 103 healers (biomedical and African indigenous healers), but only was able to have 100 respondents mention their category and 98 responded to age, while three missed due to unavoidable circumstances. During the study, the response got from the African indigenous healers show that African indigenous medicine and healing practices in Mbarara Municipality majorly include:

- Bone-setters (Ababungib'amagufa $)^{1}$ : Seven bone-setters interviewed said they use spiritual telepathy, herbs, sticks, massage with hands among other methods

- Snake poison healers (Abarumuzibobutwabw'enzoka) ${ }^{2}$ : The study interviewed two snake poison healers. They tie a belt $\left(\right.$ omweko $\left.^{3}\right)$ on-top of the area/part of body bitten by the snake and the poison will not proceed to other body parts. They also cut and suck out the poison

- Witch doctors $\left(A b a f u m u^{4}\right)$ : The researcher was able to interview five witchdoctors. These tap the sky spirits and use them to punish or kill the wrong doers for example thieves, murders and

\footnotetext{
${ }^{1}$ Ababungib'amagufa: People with knowledge to heal bones (broken and these with other sickness)

${ }^{2}$ Abarumuzib'enzoka: These are specialists who treat/remove snake poison from the body

${ }^{3}$ Omweko: This refers to a cloth belt that is used mostly by women and believed to have the power of stopping snake poison from spreading to other parts of the body once tied near the place of the bite.

${ }^{4}$ Omufumu: Healer or doctor and not a 'witch' as understood by western world.
} 
adulterers. The witches sacrifice human beings, 'go' under the water of lakes, rivers and lakes to seek riches and even some have supernatural powers.

- Herbalists (Abebishaka ${ }^{5}$ ): The study interviewed 13 herbalists. These use natural herbs to heal and cure various diseases. Some administer them when boiled and others give them in raw form. They claim to have knowledge on many diseases and their cure. The study found out that all traditional healers have knowledge on usage of herbs in many forms.

- Spiritualists (Abacwezi, Abamahembe) ${ }^{6}$ : The study interviewed 13 spiritualists. These can foretell using spirits inherited from their grandfathers or when trained. Mostly of this category were Baganda and Bahiima/cattle keepers. They claimed to be demi-gods and have special knowledge of foretelling facts, giving fortunes and even curses.

- Traditional birth attendants (Abazarisa ${ }^{7}$ ): The study interviewed 49 traditional birth attendants. Almost every African woman has the knowledge on traditional birth attendance. This knowledge is taught to girls by their mothers and aunties: when they grow up, some become more involved than others but all have some knowledge on fertility/fecundity, conception, pregnancy, and giving birth and after birth. They have a vast knowledge on the use of herbs to look after womanhood and childhood.

- Rain makers (Abaamuzi/Abaihigib'enzura): Contrary to the past where individuals earned fame for rain making during long dry spells, droughts, wrath, condemnation and even killing whenever their mysteries trades failed them, the current ones are needed during the rainy seasons. The skills of blocking or killing rain from falling are known as okwamura or okwitaenjuura. It has become a source of income for some individuals and groups who want to hold social, political, educational functions or any other in open space or "gardens" as that space is amiably referred to. They mostly benefit during weekends: the bonanza days for expensive functions. Abaamuzi or abaitsib'enzuura are normally hired by people with functions and burials to stop rain. What saves the day for those who run out luck from being subjected to ridicule, is the proliferation of the hired tents. It has become fashionable to hire tents regardless of whatever weather expectation and preventive measures by the abahaniki. It needs to be noted that while the original ones had the mandate to solve social problems, the current ones are for addressing individual problems. The nature of the budgets for these functions and the plans makes the stakes high. This gives a high bargaining power for this strand of rainmaking or killing.

It was found out that overall, the majority of African indigenous healers according to the category of these respondents were females 68\%. This means that females are more involved in African indigenous medicine and healing knowledge as mothers: they interact more with natural environment, family and societal problems, and always seek remedies for harm and problems. This data shows that the majority of healers have the experience of family and community issues thus their practices are grounded in societal beliefs, attitudes and harm that determine their healing knowledge.

It was found out that majority of healers were above age of 55 years $35 \%$. However, it was noted that young people (25-34 years) are also involved in indigenous African healing activities $16 \%$ especially in practices of traditional birth attendance $21 \%$, herbalism $38 \%$ and bone-setting $14 \%$. The implication of the age showed that most of the African indigenous healers were mature people $84 \%$ : 35-60+ years and know what they are doing: whether the practices were traded, misused, fake or true, they were liable and responsible their activities.

The researcher investigated the marital status of African indigenous healers in Mbarara Municipality and its relationship with African indigenous medicine healing knowledge. Data in table 3.6 indicates that most of the healers are married 58\%. There were $22 \%$ singles and most of them were traditional birth attendants $26 \%$. There were $18 \%$ widows/widowers and $2 \%$ divorced healers. This data shows that the majority of African indigenous healers have the experience of family and community issues thus their practices are grounded in societal beliefs, attitudes and harm that determine their healing.

\footnotetext{
${ }^{5}$ Ebebishaka: Refers to people with knowledge about the bush/herbs.

${ }^{6}$ Abacwezi, Amahembe, Emisambwa : These are African demi-gods and spirits believed to be the living dead that have connections with the living people and have power of their well-being.

${ }^{7}$ Abazarisa: These are specialists in issues concerned with pregnancies, baby delivery and post-natal care.
} 
Table 1.5 shows sex, age and marital status of African indigenous healers and biomedical health practitioners in Mbarara Municipality.

Table 1.5: Sex, Age and Marital status of LAH in Mbarara Municipality, Uganda

\begin{tabular}{|c|c|c|c|c|c|c|c|c|c|c|c|c|c|c|c|c|c|c|c|c|c|c|}
\hline \multirow{3}{*}{$\begin{array}{l}\text { African } \\
\text { Healers }\end{array}$} & \multirow{2}{*}{\multicolumn{2}{|c|}{ Traditional }} & \multicolumn{4}{|l|}{ Sex } & \multicolumn{8}{|l|}{ Age } & \multicolumn{8}{|c|}{ Marital Status } \\
\hline & & & \multicolumn{2}{|l|}{ Male } & \multicolumn{2}{|c|}{ Female } & \multicolumn{2}{|l|}{$25-34$} & \multicolumn{2}{|l|}{$35-44$} & \multicolumn{2}{|c|}{$45-54$} & \multicolumn{2}{|c|}{ 55-60+ } & \multicolumn{2}{|c|}{ Married } & \multicolumn{2}{|c|}{ Single } & \multicolumn{2}{|c|}{\begin{tabular}{|l|} 
Widow \\
Widower
\end{tabular}} & \multicolumn{2}{|c|}{ Divorced } \\
\hline & freq & $\%$ & freq & $\%$ & freq & $\%$ & freq & $\%$ & freq & $\%$ & freq & $\%$ & freq & $\%$ & freq & $\%$ & freq & $\%$ & freq & $\%$ & freq & $\%$ \\
\hline TBAs & 49 & 49 & 04 & 8 & 45 & 92 & 10 & 21 & 15 & 31 & 12 & 25 & 11 & 23 & 23 & 54 & 11 & 26 & 07 & 16 & 02 & 05 \\
\hline Herbalists & 13 & 13 & 07 & 54 & 06 & 46 & 05 & 38 & 02 & 15 & 03 & 23 & 03 & 23 & 07 & 54 & 04 & 31 & 02 & 15 & 00 & 00 \\
\hline Spiritualists & 13 & 13 & 06 & 46 & 07 & 54 & 00 & 00 & 00 & 00 & 02 & 17 & 10 & 83 & 06 & 50 & 03 & 25 & 03 & 25 & 00 & 00 \\
\hline $\mathrm{H} /$ Inspectors & 09 & 09 & 06 & 67 & 03 & 33 & 00 & 00 & 03 & 33 & 05 & 56 & 01 & 11 & 07 & 78 & 01 & 11 & 01 & 11 & 00 & 00 \\
\hline Bone-setters & 07 & 07 & 04 & 57 & 03 & 43 & 01 & 14 & 01 & 14 & 02 & 29 & 03 & 43 & 04 & 57 & 01 & 14 & 02 & 29 & 00 & 00 \\
\hline $\begin{array}{l}\text { Witch- } \\
\text { doctors }\end{array}$ & 05 & 05 & 03 & 60 & 02 & 40 & 00 & 00 & 00 & 00 & 01 & 20 & 04 & 80 & 03 & 60 & 00 & 00 & 02 & 40 & 00 & 00 \\
\hline Rain-makers & 02 & 02 & 01 & 50 & 01 & 50 & 00 & 00 & 00 & 00 & 00 & 00 & 02 & $\begin{array}{r}10 \\
0\end{array}$ & 02 & 100 & 00 & 00 & 00 & 00 & 00 & 00 \\
\hline $\begin{array}{l}\text { Poison } \\
\text { Healers }\end{array}$ & 02 & 02 & 01 & 50 & 01 & 50 & 00 & 00 & 01 & 50 & 01 & 50 & 00 & 00 & 02 & 100 & 00 & 00 & 00 & 00 & 00 & 00 \\
\hline Total & 100 & 100 & 32 & 32 & 68 & 68 & 16 & 16 & 22 & 22 & 26 & 27 & 34 & 35 & 54 & 58 & 20 & 22 & 17 & 18 & 02 & 02 \\
\hline
\end{tabular}

The findings as shown in Table 1.5 indicate that the three health inspectors were at the level of University, three attended secondary school, and while one had primary level education (two health inspectors avoided giving their education standards). This showed that there was a gap of inspection because the majority of health inspectors were not University graduates thus lacked grounded knowledge in health practices. It was also discovered that 35 of traditional healers had secondary education level (mostly drop-outs of senior one to senior three), twenty two were primary school drop-outs and four had informal education. This had a direct answer to the question of why most of them are not qualified to treat the diseases they claim to heal especially herbalists: they do not possess the training in medicine but use try and error methods in treating diseases. Important to note, there were five African indigenous healers (TBAs: 4 and Herbalists: 1) who had University education. On further investigation to these TBAs and Herbalists, they said that they inherited the healing powers form our grandparents' spirits. Pretorius (1999), argue that for some communities, traditional knowledge takes on a personal and spiritual meaning but based on educational levels. Thus, African indigenous medicine and healing knowledge can also reflect a community's interests dependent of education levels and some communities depend on their indigenous medicine and healing knowledge for survival.

Table 1.6 shows nationality and education levels of African indigenous healers in Mbarara Municipality, Uganda.

Table 1.6: Nationality and Educational levels of LAHs Mbarara Municipality, Uganda

\begin{tabular}{|c|c|c|c|c|c|c|c|c|c|c|c|c|c|c|c|c|c|c|}
\hline \multirow[t]{3}{*}{ ATH } & \multicolumn{10}{|c|}{ Nationality } & \multicolumn{8}{|c|}{ Education Levels: } \\
\hline & \multicolumn{2}{|c|}{ Congolese } & \multicolumn{2}{|c|}{ Kenyan } & \multicolumn{2}{|c|}{ Rwandan } & \multicolumn{2}{|c|}{ Ugandan } & \multicolumn{2}{|c|}{ Tanzanian } & \multicolumn{2}{|c|}{ University } & \multicolumn{2}{|c|}{ Secondary } & \multicolumn{2}{|c|}{ Primary } & \multicolumn{2}{|c|}{$\begin{array}{l}\text { Informal } \\
\text { Education }\end{array}$} \\
\hline & freq & $\%$ & freq & $\%$ & freq & $\%$ & fireq & $\%$ & freq & $\%$ & freq & $\%$ & freq & $\%$ & freq & $\%$ & freq & $\%$ \\
\hline TBAs & 01 & 02 & 01 & 02 & 02 & 04 & 36 & 80 & 05 & 11 & 04 & 10 & 18 & 46 & 15 & 39 & 02 & 5 \\
\hline Herbalists & 00 & 00 & 00 & 00 & 00 & 00 & 12 & 92 & 01 & 8 & 01 & 10 & 09 & 90 & 00 & 00 & 00 & 00 \\
\hline Spintualists & 02 & 15 & 00 & 00 & 01 & 8 & 08 & 62 & 02 & 15 & 00 & 00 & 02 & 40 & 03 & 60 & 00 & 00 \\
\hline Bone-setters & 01 & 14 & 00 & 00 & 00 & 00 & 06 & 86 & 00 & 00 & 00 & 00 & 01 & 33.3 & 02 & 66.7 & 00 & 00 \\
\hline Health Inspectors & 01 & 14 & 00 & 00 & 00 & 00 & 06 & 86 & 00 & 00 & 03 & 43 & 03 & 43 & 01 & 14 & 00 & 00 \\
\hline Witch doctors & 00 & 00 & 00 & 00 & 00 & 00 & 03 & 100 & 01 & 1.1 & 00 & 00 & 00 & 00 & 01 & 100 & 00 & 00 \\
\hline Rain makers & 00 & 00 & 00 & 00 & 00 & 00 & 02 & 100 & 00 & 00 & 00 & 00 & 00 & 00 & 00 & 00 & 02 & 100 \\
\hline Poison Healers & 00 & 00 & 00 & 00 & 00 & 00 & 02 & 100 & 00 & 00 & 00 & 00 & 02 & 100 & 00 & 00 & 00 & 00 \\
\hline Total & 05 & 5.4 & 01 & 1.1 & 03 & 3.0 & 75 & 80.6 & 09 & 9.7 & 08 & 11.8 & 35 & 50.7 & 22 & 32.3 & 04 & 5.9 \\
\hline
\end{tabular}




\subsection{Responses from Beneficiaries/Patients}

The researcher interviewed beneficiaries/patients in all the six divisions of Mbarara Municipality, Uganda to have their views about African indigenous medicine and healing knowledge. It was established that most of the beneficiaries were farmers (44\%) with many females (67\%): this means they are living in the peri-urban areas, have access to African indigenous healers, believe in culture and traditions. Generally it was found out that the number of males $(56 \%)$ is slightly higher than those of females (44\%) that benefit from African indigenous medicine and healing knowledge. This did not confirm clearly that men visit traditional healers most but shows that both males and females benefit from African indigenous medicine and healing practices as argued by Truter (2007) that approximately $90 \%$ of healers in Africa are male.

It was found out that mostly the married $(60.7 \%)$ are the beneficiaries of African indigenous medicine and healing knowledge and within that group the farmers and lecturers had a higher number $(75 \%)$ and $(75 \%)$ respectively. This implied that the married people are faced with more health related problem (diseases and social problems) that entice them to visit/seek services of African indigenous healers. Also, teachers and traders had 67\% and 50\% representation as beneficiaries of African indigenous medicine and healing knowledge (IAMHK). It was also found out that the singles also had a considerable number (32\%): this meant that the singles also were faced with social harm (diseases, unemployment among other problems) that makes them visit African indigenous healers. The widow/widowers and divorced had less frequency (one each): these were found to be more than fifty years of age and meant that they had no serious concerns with societal problems. Khasbagan and Soyolt (2008), argue that indigenous knowledge is understood as the systematic information that resides in diverse social structures that include marital status.

Table 1.7: Sex, Age and Marital status of Beneficiaries in Mbarara Municipality, Uganda

\begin{tabular}{|c|c|c|c|c|c|c|c|c|c|c|c|c|c|c|c|c|c|c|}
\hline Beneficiaries & \multicolumn{4}{|l|}{ Sex: } & \multicolumn{6}{|l|}{ Age } & \multicolumn{8}{|c|}{ Marital Status } \\
\hline \multirow[t]{2}{*}{ Occupation } & \multicolumn{2}{|c|}{ Male } & \multicolumn{2}{|c|}{ Female } & \multicolumn{2}{|c|}{$25-34$} & \multicolumn{2}{|c|}{$35-44$} & \multicolumn{2}{|l|}{$45+$} & \multicolumn{2}{|c|}{ Married } & \multicolumn{2}{|c|}{ Single } & \multicolumn{2}{|c|}{$\begin{array}{l}\text { Widow } \\
\text { Widower }\end{array}$} & \multicolumn{2}{|c|}{ Divorced } \\
\hline & freq & $\%$ & freq & $\%$ & freq & $\%$ & freq & $\%$ & freq & $\%$ & freq & $\%$ & freq & $\%$ & freq & $\%$ & freq & $\%$ \\
\hline Farmers & 04 & 33 & 08 & 67 & 01 & 09 & 07 & 64 & 03 & 27 & 09 & 75 & 02 & 17 & 01 & 8 & 00 & 00 \\
\hline Students & 02 & 100 & 00 & 00 & 02 & 100 & 00 & 00 & 00 & 00 & 00 & 00 & 02 & 100 & 00 & 00 & 00 & 00 \\
\hline Teachers & 01 & 33 & 02 & 67 & 01 & 33 & 00 & 00 & 02 & 67 & 02 & 67 & 01 & 33 & 00 & 00 & 00 & 00 \\
\hline Traders & 03 & 75 & 01 & 25 & 02 & 50 & 00 & 00 & 02 & 50 & 02 & 50 & 01 & 25 & 00 & 00 & 01 & 25 \\
\hline Administrators & 01 & 100 & 00 & 00 & 01 & 100 & 00 & 00 & 00 & 00 & 00 & 00 & 01 & 100 & 00 & 00 & 00 & 00 \\
\hline Technicians & 02 & 100 & 00 & 00 & 01 & 50 & 00 & 00 & 01 & 50 & 01 & 50 & 01 & 50 & 00 & 00 & 00 & 00 \\
\hline Lecturers & 02 & 67 & 01 & 33 & 02 & 100 & 00 & 00 & 00 & 00 & 03 & 75 & 01 & 25 & 00 & 00 & 00 & 00 \\
\hline Total & 15 & 56 & 12 & 44 & 10 & 40 & 07 & 28 & 8 & 32 & 17 & 61 & 09 & 32 & 01 & 4 & 01 & 4 \\
\hline
\end{tabular}

Table 1.8: Nationality and Educational levels of beneficiaries/patients in Mbarara Municipality, Uganda

\begin{tabular}{|c|c|c|c|c|c|c|c|c|c|c|c|c|c|c|}
\hline Beneficiaries/Patients & Natior & & & & & & Educ & tion & evels & & & & & \\
\hline Occupation & Ugand & & Rwar & & Tanz & aian & Univ & sity & Secol & lary & Prim & & Infol & \\
\hline & freq & $\%$ & freq & $\%$ & freq & $\%$ & freq & $\%$ & freq & $\%$ & freq & $\%$ & freq & $\%$ \\
\hline Farmers & 08 & 80 & 02 & 20 & 00 & 00 & 04 & 10 & 18 & 46 & 15 & 39 & 02 & 5 \\
\hline Students & 02 & 100 & 00 & 00 & 00 & 00 & 01 & 10 & 09 & 90 & 00 & 00 & 00 & 00 \\
\hline Teachers & 03 & 100 & 00 & 00 & 00 & 00 & 00 & 00 & 02 & 40 & 03 & 60 & 00 & 00 \\
\hline Traders & 02 & 50 & 00 & 00 & 02 & 50 & 00 & 00 & 01 & 33 & 02 & 67 & 00 & 00 \\
\hline Administrators & 01 & 100 & 00 & 00 & 00 & 00 & 03 & 43 & 03 & 43 & 01 & 14 & 00 & 00 \\
\hline Technicians & 02 & 100 & 00 & 00 & 00 & 00 & 00 & 00 & 00 & 00 & 01 & 100 & 00 & 00 \\
\hline Lecturers & 03 & 100 & 00 & 00 & 00 & 00 & 00 & 00 & 00 & 00 & 00 & 00 & 02 & 100 \\
\hline Total & 21 & 84 & 02 & 08 & 02 & 08 & 08 & 13 & 23 & 34 & 22 & 32 & 04 & 6 \\
\hline
\end{tabular}

केource: Beneficiaries/Patients (Field data, 2015) 
Table 1.8, show that most of the respondents (78\%) had formal education: however, this this did not make them visit traditional healers but instead made them aware of African indigenous medicine and healing knowledge. Instead, it was found out that those who had formal education level (5.9\%) accessed more African indigenous medicine and healing practices. This meant that education levels matter in accessing African indigenous medicine and knowledge: the more one is ignorant about health matters, the more he can be lured to visit different forms of healing. Friction is evident between 'Western' medicines or biomedicines that look at 'material causation' to understand and treat an illness; and traditional medicine that generally looks towards the 'spiritual' origin such as witcheraft and displeasure by ancestors in order to cure an ailment.

The researcher further analysed all the data from the total sample of 192 that included leaders, healers' committees, healers and beneficiaries/patients from the questionnaires, interviews and group discussion to establish community development activities and African indigenous medicine and healing knowledge in Mbarara Municipality. Response showed that the activities of African indigenous medicine and healers included spiritualism (Abacwezi, amahembe, ebitega, emandwa) ${ }^{8}$, especially being practiced by healers from DRC, Tanzania, Buganda and Bunyaruguru. One respondent from the interview session said:

“......they have names as JjajaKingungwewaNgungwekutokka Zanzibar, Kojja Sembayitao kuva Kkoki, Mzee Ssalongo Zigagwana, Ssenga Bbuladde......., they claim to have power from under the water and in the skies...." (Field interview, November, 2015).

It was found out that the African indigenous medicine and healing knowledge include bone-setting (these combine spirituality, herbal and use of modern medicine): the mostly common bone-setters in Mbarara Municipality are the members of the family of Rutamaguza. Response also indicated the existence of African indigenous medicine and healers who treat snake bites using local knowledge. It was also established that in Mbarara Municipality there are training services for becoming a traditional healer: these trainings are mostly in herbal medicine but as well in other forms of healing e.g. spirituality (installing spiritual powers) and birth attendance (knowledge and skills). The study established that there are rehabilitative services offered by traditional healers for example giving counselling to families with problems, sex education to women among many others. Information got from the field is supported and rhythm with arguments of Manderet al. (2006) that the average frequency of consulting with a traditional healer in Africa is 4.8 times per year.

\begin{tabular}{|c|c|c|c|c|c|c|c|c|c|c|}
\hline \multirow[t]{3}{*}{ Activities } & \multicolumn{10}{|c|}{ Response } \\
\hline & \multicolumn{2}{|c|}{$\begin{array}{c}\text { Leaders } \\
\mathbf{N}=\mathbf{2 7}\end{array}$} & \multicolumn{2}{|c|}{$\begin{array}{c}\text { NCTHHAs } \\
\mathbf{N}=\mathbf{3 0}\end{array}$} & \multicolumn{2}{|c|}{$\begin{array}{c}\text { Healers } \\
\mathrm{N}=103\end{array}$} & \multicolumn{2}{|c|}{$\begin{array}{c}\text { Beneficiaries } \\
\mathbf{N}=\mathbf{3 0}\end{array}$} & \multicolumn{2}{|c|}{$\begin{array}{c}\text { Total } \\
\mathrm{N}=190\end{array}$} \\
\hline & freq & $\%$ & freq & $\%$ & frea & $\%$ & freq & $\%$ & frea & $\%$ \\
\hline Herbalism & 27 & $10 O$ & 26 & 87 & 82 & 80 & 28 & 93 & 163 & 86 \\
\hline Spiritualism & 26 & 96 & 25 & 83 & 56 & 54 & 12 & $4 O$ & 119 & 63 \\
\hline Rain-making & 27 & $10 O$ & 25 & 83 & 56 & 54 & 08 & 27 & 116 & 61 \\
\hline Mid-wifery & 12 & 44 & 24 & 80 & 34 & 33 & 25 & 83 & 95 & 50 \\
\hline Training services & 10 & 37 & 18 & 60 & 43 & 42 & 11 & 37 & 82 & 43 \\
\hline Rehabilitative services & 9 & 33 & 15 & 50 & 28 & 27 & 06 & 20 & 58 & 37 \\
\hline TBAs & 24 & 89 & 28 & 93 & 89 & 86 & 26 & 87 & 167 & 88 \\
\hline
\end{tabular}

Table 1.9 above, shows the activities of African indigenous medicine healing knowledge (AIM) in Mbarara Municipality and these include giving herbs and bone-setting, traditional birth attendance, spirituality, foretelling and snake poison healing. This affirms various activities carried out by African traditional healers as highlighted by other scholars (Doornbos, 1978; Mbiti, 1978 \& 1989). Thus the World Health Organization (2008), explain traditional medicine as the health practices, approaches, knowledge and beliefs incorporating plant, animal and mineral based medicines, spiritual therapies,

\footnotetext{
${ }^{8}$ These names of spirits depend on the tribe: Abacwezi (Ankore, Tooro, Rwanda), Amahembe (Buganda), Emandwa (Buganda, Toro, Bunyoro, Tanzania), Ebitega (Burundi, DRC, Rwanda).

${ }^{9}$ The names of spiritualists also will tell where one originates e.g from Zanzibar (where most powerful ones come from): it is noted that each origin has its own speciality in the spiritual power.
} 
manual techniques and exercises, applied singularly or in combination to treat, diagnose and prevent illnesses or maintain well-being. It also acknowledges tradition medicine as the sum total of knowledge, skills, and practices based on the theories, beliefs, and experiences indigenous to different cultures that are used to maintain health, as well as to prevent, diagnose, improve, or treat physical and mental illnesses.

Table 1.9 shows involvement in the activities of AIM in Mbarara Municipality. It was established from respondents that African indigenous healers are mostly involved in traditional birth attendance $(88 \%)$, followed by herbalism $(86 \%)$, bone-setters $(85 \%)$, spirituality $(63 \%)$, rain-makers $(61 \%)$, midwifery $(50 \%)$, training services (43\%), foretelling (35\%) and rehabilitative services (31\%). The respondents $(43 \%)$ confirmed also that training and practicing/usage of African medicine and healing knowledge was done on a pay/cost principle by trainees. Most of the training was in herbalism, midwifery and spirituality (okuhangaamahembe ${ }^{10}$ okutatsyaabacwezi ${ }^{11}$ ).

Also, the response got from NCTHHA committees showed that there is counselling and rehabilitative services mostly given to families with wrangles and usually is done by old men and women known as uncles and aunties (Ssenga ${ }^{12}$ ). The researcher through the interviews with both modern and African indigenous healers in Mbarara Municipality responded that there was existence of various activities of African indigenous medicine and healing knowledge. One respondent said:

“....an indigenous African healer without knowledge of birth attendance.... giving fertility, looking after pregnancy, helping a woman to give birth and looking after the mother and child after birth....is not a traditional healer...healing is done to human being brought to the world by mothers..." (Field interview, November, 2015).

The above statement shows that the African indigenous medicine-people and healers are aware of the healing activities.

\subsubsection{Herbalism}

The research found out that herbalism used to be mostly carried out at domestic levels but of recent has become commercialized and industrialized: the herbs are given as raw, while others are boiled, dried and even bottled into drinking and jelly to treat various diseases. Blended and bottled herbs by Kazaire, Amatsiko, Tayebwa, and Tweyambe, and have flooded the market. ${ }^{13}$. It has been argued that unemployment and poverty are forcing communities to generate income by selling plant species of medicinal value (Coopoosamy\&Naidoo, 2011, Magoro, 2008). The harvesting and selling of medicinal plants is an example of how people, especially women, from mainly rural communities and households, generate income from trading in forest and woodland products (Williams, 2004). According to Hauff (2002), poverty forces many rural people to extract too many valuable resources to allow for natural regeneration to occur. Poverty also contributes to the trade in natural resources, which if not well managed can lead to species loss (Bodeker, 2005). The exploitation of natural resources for selling has resulted in significant effects to community development for the communities (Moeng, 2010 and Williams, 2007). Women in Mbarara Municipality are engaged in selling herbs to generate income and as cure diseases of infants and children, and women/mother related post-natal, fertility, sex-potent healing diseases, increase of libido, skin rushes and ulcers, stomach-ache and many others.

The researcher visited Mbarara central market and found a lucrative business of selling various herbs. Clients and the sellers confirmed to the researcher that these herbs help to treat various diseases especially for young children through bathing and oral drinking: the former known as eshabiko/ekyogero and the latter as emizumburiro.

\footnotetext{
${ }^{10}$ Okuhangaamahembe : Training and ordaining someone with Baganda spirits known as Jaja or Mayembe

${ }^{11}$ Okutatsyaabacwezi: Enshrining and enthroning a person with the demi-god spirits of herdsmen known as abacwezi in a home.

${ }^{12}$ Ssenga: Old women with knowledge about family affairs (cooking, love-making, children care etc) and can ably counsel members of families with problems

${ }^{13}$ The trade names e.gKazaire $=$ 'Parent', Amatsiko $=$ 'Hope', Tayebwa $=$ 'Does not forget', have a meaning and express the intentions of the healer: these names also entice the patient to access the medicine.
} 


\section{Plants for herbs}

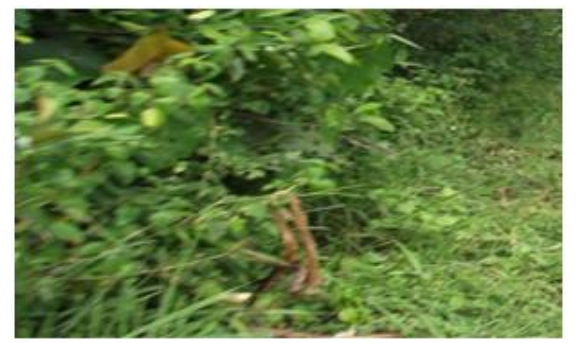

Plate1.1a. Akabindizi (Nicotianatabacum)

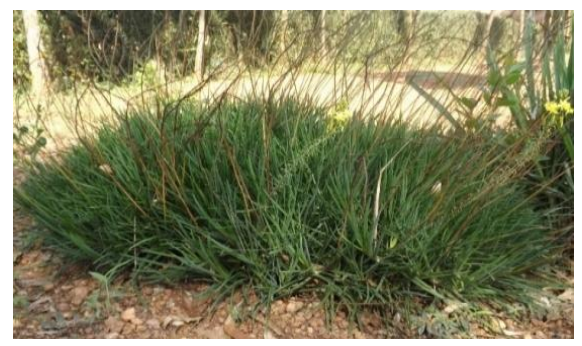

Plate1.1b. Obunyanyanbuzi (Montiaslinearis)

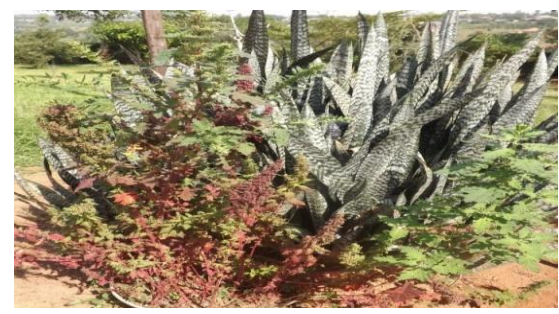

Plate1.1c. Omujeejeand akagaigo(myricasalifolia and Agave sisalana)

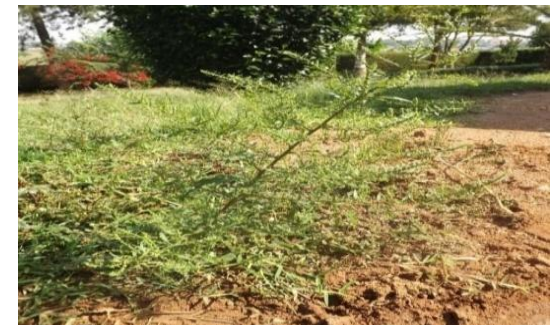

Plate1.1d. Akabingabaziimu(clematis hirsutissima)

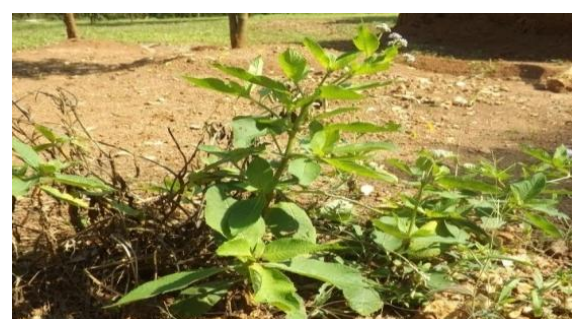

Plate1.1e. Ekyoganyanza (Erlangeatomentosa)

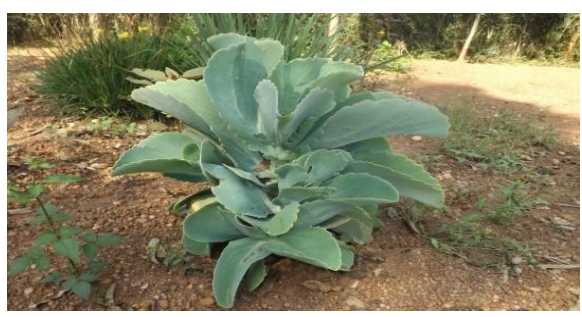

Plate1.1f. Ekinyondo (KalanchoedensifoliaRolfe)

Source: Plants-herbs sampled from various villages in Mbarara Municipality (Field data, 2015) 
The researcher interviewed herbalists and they gave samples of plants used for medicine extraction. Plate 1.1a shows a plant locally known akabindinzi which is used to make herbs that treat various diseases: children rashes, stomach pains. The leaves and roots are cooked and children are bathed with that mixture when warm which is believed to cure rashes and other comprehensive skin diseases often for post-natal treatment. Akabindinzi is also drunk by pregnant women as orals believed to heal many diseases related with pre-natal treatment: one of the herbalist said:

“......omukaziw' endayabaatateirweamaizi, omwananakuuraaineendwara, akabindinzin' omubazigurikutambaomuburan' endwaraz'abakazi..." Translation: “.....A pregnant woman needs to be cleaned, because the foetus will grow with diseases, akabindinzi is a drug that heals pregnancy diseases....."

Plate $1.1 \mathrm{~b}$ shows a plant locally named Obunyunyambuziwhich is used by African traditional herbalist to increase vaginal fluids during sex. It is crushed and mixed with other herbs and drunk orally by women believed to be 'dry' during sex. Also, the crushed obunyunyambuzi are used for washing the vagina, for pulling to elongate (okunyurura) the parts of the vagina believed to arouse the feelings during sex. The herbalist confirmed that many women come for receiving this treatment although such clients always request this to be done in secrecy.

Usage of herbs sampled, one of the herbalists said that most herbs were used to treat many diseases as shown by Plate 1.1c. The explanation was that these two plants omujumbajumbaand akagorora are planted together to give security to homes, they send away night dancers,protectthe home from bad spirits. It was also found out that these plants are squeezed and their liquid/juice can be drunk as medicine to heal various diseases that include stomach pains and can cure bad/evil spirits when rubbed on the patient's nose and skin especially the head parts.

Plate $1.1 \mathrm{~d}$ shows a plant locally called akabinga-baziimu which is specifically used to treat someone who has been attacked by evil spirits. It is squeezed and liquid drunk by the patient to remove the evil spirits from the body and the smelly dregs are rubbed all-over the body that will scare away the sent bad spirits to the person.

More response revealed that pre-natal and post-natal treatment is mostly done using herbs. Plate 1.1e shows a plant locally known as ekyoganyanza which is mixed with other herbs (enshabiko: that works as steam bath) when bathing the newly born babies and is highly believed to treat a comprehension of diseases. A mixture of this herbal medicine is used by pregnant women as oral drink and bathing potent mixed with other herbs.

Plate 1.1f shows three plant (big leaves bluish $=$ ekinyondo, , black jack $=$ obukururaand lemon grass $=$ omutete), Ekinyondois used to treat ear diseases: it roasted and squeezed out liquid is poured in the ear and cleaned is done using a chicken-feather. While the obukurura (black jack) have various treatments: it is used to treat wounds (tied on the wound directly), and as well for preparing the brides sexual parts [for elongating (okunyurura) and massaging the vagina parts in preparation for sex at marriage.
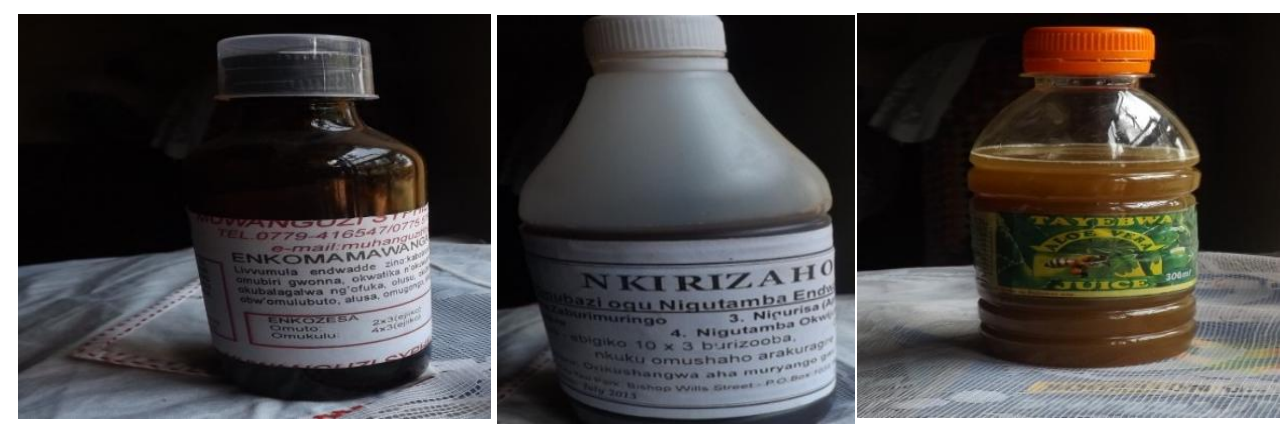

Plate1.2. Sampled bottled drugs in Mbarara Mucipality, Uganda

Source: Sampled bottled African indigenous herbs (Field data, 2015)

The researcher made further investigation on bottled herbs by different herbalists: the sampled products included Muwanguzi, Nkirizaho, Tayebwa and Kazaire products as shown in Plate 1.2. Further analysis showed that the prescriptions on those bottled herbs claimed to cure many diseases: gives appetite, cures cancer, stomach pains, sex libido among many others. These bottled herbs are found in drug shops, markets and are sold in buses especially from Mbarara to Kampala. 
The beneficiaries/patients said that African midwifery was done on the commercial basis. This begins with women and men looking for fertility, libido for men and women, 'fluids/sweetness/water' ${ }^{14}$ in love making, love portions among many others. They also visit traditional birth attendants (especially old women who have unique African indigenous medicine and healing knowledge) to have medicine for pregnancy care (okuteraamaizienda/ okurebereraend $a^{15}$ ): they are given herbs, pregnancies checked and even spirits consulted for blessing. The study found out that herbs are also used by midwifery in postnatal period (after delivery of babies) to treat the mothers and babies in various diseases (Ekyogero/Esabiko $\left.{ }^{16}\right)$.

\subsubsection{Bone-Setting}

The patients are treated using rudimentary methods of tying sticks around the broken area, massaging with cow ghee and warm water to re-align the broken bones. Even modern medicine and injections are given to patients to cure injuries and septic parts of the body. Some of the patients interviewed said that:

"......we had first visited the main hospital but later transferred here..... the healing was goingon well despite of spending much money, being crowded here...the "doctor" (Omubungi ${ }^{17}$ ) has no mercy when re-aligning the broken part, he is rough and uses a lot of energy without sterilising the part... he works on us only three days a week (Monday, Wednesday and Fridays), the rest of the days we do exercises by trying to walk around using supporting sticks/crutches...." (Field interview, November, 2015)

In-depth discussion with the beneficiaries/patients revealed that these bone-setters use "unknown knowledge" 18 combined with herbs and modern medicine to cure and heal broken parts of the body: one of the beneficiaries said:

“.... I was shifted to this place after failing to heal at a government hospital....he can align your bones even without physically touching or massaging the part of the body... he usually does that in the evening or very early in the morning using spiritual power...I am now walking, my wounds are healed and soon will be discharged.... "(Field interview, November, 2015).

The research findings confirmed that patients pay money to this local bone-setter and are aware that he is not a modern trained orthopedician/ omubungi. The patients revealed that they know it is risky but still run away from the modern health facilities (Mbarara referral hospital and other many hospitals and clinics which are even near this local bone-setter's home) to come and seek this local bone-setting because many have been healed by this African traditional healer.

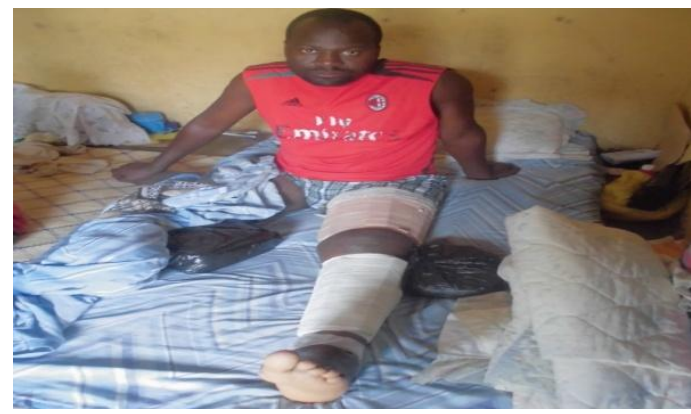

Plate 1.3: Patient under bone-setting

Source: A patient being treated at 'Dr'. BantarizaRutamaguza on Mbarara-Kabale Road, in RutiMbarara Municipality (Field data, December, 2015): (The Researcher got permission from the patient for his photograph to appear in this text)

\footnotetext{
${ }^{14}$ Fluids/sweetness/water: it is expected that a woman should be very wet with watery fluids during sex and those who are dry are not sweet, most women visit SSenga = aunties to have herb concoctions believed to increase those fluids.

${ }^{15}$ Okuteraamaizienda/okurebereraenda: This is an activity done by old women to pregnancies, they bathe pregnant women with mixture of herbs believed to treat diseases.

${ }^{16}$ Ekyogero/Esabiko: Mixture of all herbs but without thorns is collected and sometimes boiled, and this used to bathe newly born children to cleanse and treat them of diseases

${ }^{17}$ Omubungi: Healer/ Assembler/Aligner of bones.

${ }^{18}$ Unknown power $=$ spiritual power that works in telepathy commonly known as spiritual connections
} 


\subsubsection{Spiritualism}

The study further investigated whether there were activities of spiritualists in Mbarara Municipality, Uganda. The response by various healers show that there is spiritualist activity on a commercialized level: these included Abacwezi $i^{19}$, Amahembe ${ }^{20}$ among many spirits to make a diagnosis of patients' sickness and even prescribe the medicine or acts to be done to cure or heal the diseases. It was noted that spiritualists are inseparable with foretelling and always claim to know what has happened in past, present and what will happen in the future. The researcher interfaced with spiritualists in action as shown in Plate 3.5a-d

\section{Spiritualism and connections}

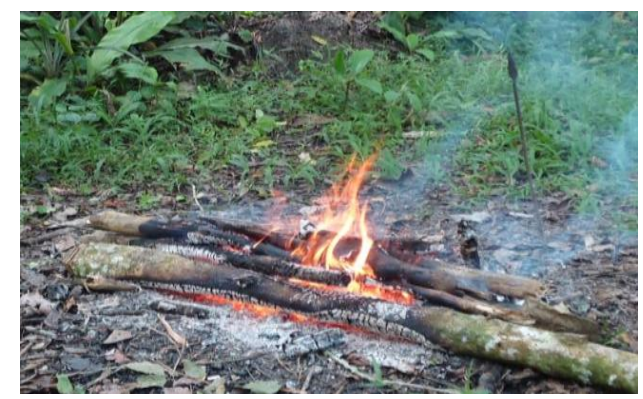

Plate1.4a. Fire burning/Ekyoto

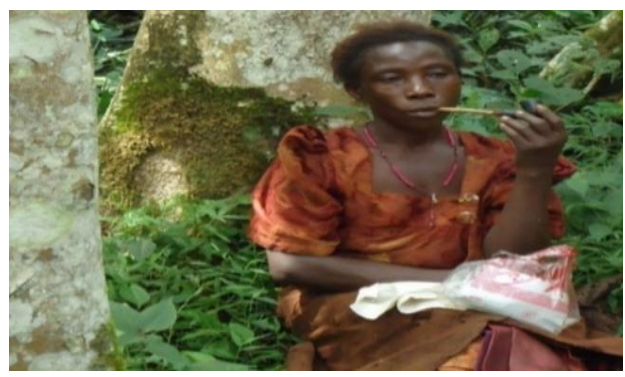

Plate1.4b. Pipe smoking/ Okuretsaenyungu

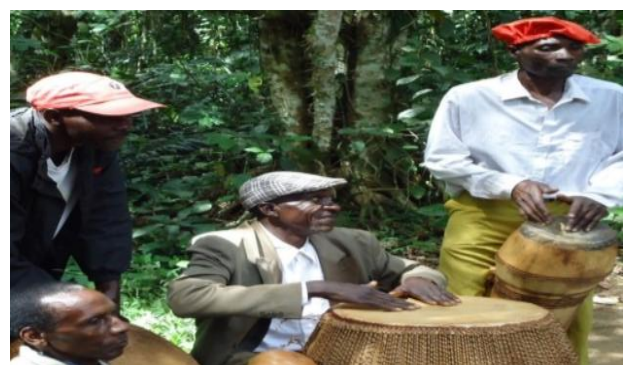

Plate1.4c. Drumming/ Okuteera engoma

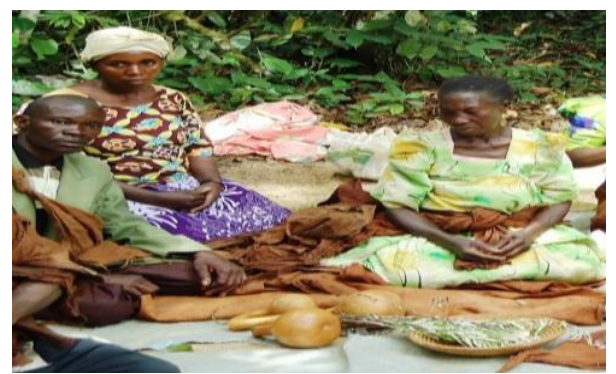

Plate1.4d. Healing session/ okukiiza

Source: Spiritualists at a healing session in Rwakishakizi, Nyakayojo Division, Mbarara Municipality, Uganda (Field data, August, 2015):(The Researcher got permission from the healers for their photographs to appear in this text)

\footnotetext{
${ }^{19}$ Abacwezi: Demi-gods of Cattle herders

${ }^{20}$ Amahembe: Baganda tribe spirits believed to be very strong in punishing wrong doers, can kill or make a person mad
} 
Plate 1.4a shows the beginning of spiritual connections: the spirualits explained that fire (ekyoto) is first lit and this symbolize power, that spirits of fore-fathers connect from the sky and underground when there $s$ existance of a bon-fire. Then, there must be a person to smoke using a pipe and concoction of herbs whose aroma enhance the spiritual connections: notably, the woman who was smoking the pipe put on a rosary as shown in Plate 1.4b. This showed a mixture of modern religion with African indigenous medicine and healing knowledge.

It was further established that the ceremony continues with drumming commonly done by men and accompanied by dancing of women as shown in Plate 1.4c. The researcher interviewed some of these spiritualists and they said the spirits (emandwa, emiziimu ya baswenkuru) of the grand parents connect with this ceremony though enchanting and calling their names (okukohora $=$ calling of spirits) according to the power these spirits have, and under the dancing process. It was found out that there were many ceremonies and procedures done in order to connect with the world of living dead.The researcher found out that once the spiritualist is connected with the spiritual powers, then s/he can foretell and heal many diseases of various patients as shown in Plate $1.4 \mathrm{~d}$.

Schoenbrun (2015) arguments '..that spirit possession and medium ship have been in play from earliest times, as revealed by the historical development of the meanings attached...'confirms the process of to "kuba'ndwa" (spirit possession and propitiation, often organized by specialists, created large evanescent publics).Spiritualists revealed that African indigenous medicine and healing knowledge is based in African Shrine activities as shown in Plate 1.4a-d and grounded in cultural, health and religious basics. The researcher interviewed an indigenous African healer of Promoting Medicine, Education, Training and Research of Africa (PROMETRA) and said:

....... man has components that include: physical body, psyche/subconscious, soul, spiritual and moral/religious aspects. The physical body is divided in three parts of biological, bio-energetic and bio-magnetic: these work together to extract foreign objects to the body, causing diseases. The psyche or subconscious part of man is responsible for illness: psychosomatic and somatopsychic since the African thought and external signs govern man's internal life. Man's subconscious is viewed as the basis for fears, weaknesses, doubts which may be causing one's ill health and disharmony. The psyche has sacred roots, it plays an important role in equilibrium, disequilibrium, harmony and disharmony: it is a root to many illness and ailments - psychosocial and spiritual support.... (Field interview, November, 2015)

Thus, spirits are understood as:

- Functions: link families together (individually and collectively) at many levels human, essentials and energy.

- There is a horizontal and vertical relationship in the extended family (the living and the dead).

- Energy is the only difference between the living and the dead and is controlled by the second level of spirits

- Levels of spirits as indicated in Plate 1.6 below:

$>$ Departed parents (the dead are not dead, we live in reincarnation).

$>$ Government of world cycles/connections (movement of energy).

$>$ Morphism resonance and universal collective memory that makes brains outside man's brain.

$>$ Major and minor predictive spirits link all creatures with one another

The spiritualist explained that there are levels of spirits in the African tradition and these help the Indigenous healers to carryout they duties in healing exercises.

“.... Spirituality is seen in clan totems (with downloadable spiritual capacities spread in all clans and have high spiritual potentials)...it seen in animals, birds, reptiles, plants, insects, fish (that is why these are used in sacrifices and medicine)...spirits exist in sacred mountains, rivers and other water bodies, forests and the sky (the powers in such places are vital in healing and punishing)...." (Field Interview, November, 2015). 
The above research findings affirm the argument that the body is a social practice that exhibits the body in spirituality (Cornaroff, 1985, Bourdieu, 1984). The utilization of medicinal plant and animal products are traditional remedies for human diseases and medical conditions in these millennia and recent years focusing on traditional medicines, folklore, home cures from traditional healers using "supernatural practices".

The researcher visited the shrines where African indigenous medicine and healing knowledge is done to ascertain powers of spirituality and witchcraft. The interviews carried out from various categories of African indigenous healers, indicated that 'witchcraft' is done by these healers but are not bad as defined by the western philosophy:

“....in Africa there is no witchcraft but a healing form where animals are sacrificed to appease the spirits, to call for power of knowledge, to punish....there is no human being sacrifice in the African medicine, those who do it, are murderers...." (Field interview, November, 2015)

The African indigenous healers begin by lighting fire, drumming and singing calling names of the spirits and then either burn whole or slaughter the birds (hens, ducks) and animals (goats, cows etc.) depending on the magnitude of the ceremony(Plates 1.4a-d). The patients/ clients is involved in the function either by smearing himself or herself with blood mixed with herbs ( medicine concoction), s/he may drink it, will be possessed and then the healing of excursion of bad spirits, giving blessings or even punishing the culprit happens. Plate 1.5 shows an activity where the indigenous African healer was giving blessing of becoming rich and the client said:

"....the healer gave me a blessing to get money by smearing ash from the burnt money on the right hand that receives money...." (Field interview, November, 2015)

In addition on blessing to have money, ornaments and objects 21 were given to give security of riches: these are supposed to be carried in the pockets or tied around the body. Kurt Alan VerBeek (2010), argue that spirituality is central to many of the daily decisions people in the 'South' (Africa) make about their own and their community's development, including that of whether or not to participate in risky but potentially beneficial social action.

\section{Spirituality: Giving powers of having riches/money}

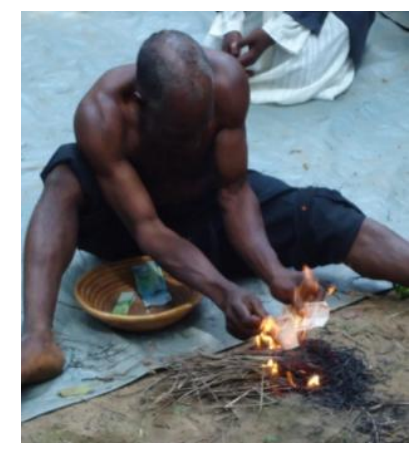

Plate1.7a. Burning money

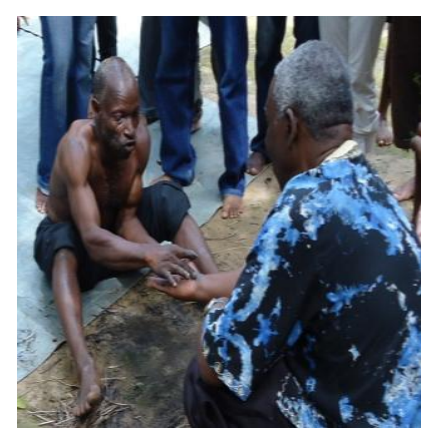

Plate1.7b. Giving the blessing

\footnotetext{
${ }^{21}$ Ornaments and objects are commonly known as Eyirizi/Ekikondo: these are put in wallets, handbags or pockets and are believed to be protective against any harm or danger from enemies or any witchcraft
} 


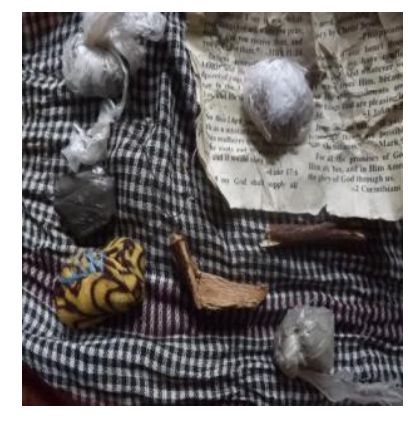

Plate1.7.c. Other ornaments

Plate 1.5a-c shows the activities of the African indigenous healer (spiritualist) giving blessings of getting rich. In Plate 1.5a, African indigenous healer burn paper money, followed by calling and enchanting spirits. The burnt paper money turned into ash that was smeared onto the right hand of the client as shown in Plate 1.5b. In addition ornaments (ehirizi/ekikondo) as shown in Plates 1.4cwere given as security to the client and were instructed that these should be kept near the body especially in the pocket. Notably, the packing materials for these ornaments were papers torn from the Bible as shown in Plate 1.4c. On whether it was accidental to use papers torn from the Bible to pack such ornaments, the African traditional healer said it was a blending style of powers from Christianity and African traditions that heal.

The research further investigated the activities done by African indigenous healers that practice foretelling (okuraanga) was also an activity. It was established from the beneficiaries that African traditional healers can tell your name, problems or what will happen without asking you first. The researcher visited shrines of foretellers in Katojo cell, Nyakayojo Division, Mbarara Municipality (Oтисwezi and Omufumu ${ }^{22}$ ) and found patients who confirmed to have been told of their names and problems, and were being treated. It is a mystery to explain how this is done, but people believe in foretelling: the process begun with the healers enchanting and calling spirits, names of gods and grandfathers and even throwing cowrie shells to give them information about the patient or beneficiary. The African indigenous healers wore hats with cowrie shells, birds' feathers, white clothes, bark clothes and animal skins, hold spears, have tables with milk (orujeje ${ }^{23}$ ), objects and ornaments and usually work in open broad day light.

It was found out that sometimes foretelling is done together with spirituality and the difference is very small: however, most spiritualists involved animal sacrifices. The response from beneficiaries indicated that spiritualist exist in Mbarara Municipality: these use grandparents spirits (emizumu ${ }^{24}$ ), acquired spirits from different parts of the world (Kifaru, Mayembe, Binegoetc ${ }^{25}$ ) to cure and heal different types of diseases. The beneficiaries/patients also confirmed that spirituality was being carried out by African indigenous healers and that these had the powers to kill and punish wrong doers. A respondent said that:

"....they can catch thieves (of stolen food stuffs, property, money etc.), kill those who have offended you (if one has taken your spouse, killed your relative)....they can punish you by becoming mad or making you behave strange...." (Field interview, November, 2015).

UNAIDS (2000), makes a number of key points in favour of collaboration with African indigenous healers. Importantly, they note that traditional healers "provide client-centre, personalised health care that is culturally appropriate, holistic and tailored to meet the needs and expectations of the patient. African indigenous healers are culturally close to clients, which facilitates communication about

\footnotetext{
${ }^{22}$ Omucwezi: these are believed to be demi-gods with power to foretell, and omufumu = etymologically is derived from 'omufu' = dead/living dead and 'mu' = with: this implies that the foreteller has powers to connect with the living dead who can give all information on a being

${ }^{23}$ Orujeje: Milk place where milk gourd and pots are put to appease Bacwezi gods believed to be herdsmen and leaders of Bantu tribe

${ }^{24}$ Emizimu: Grandparents spirits believed to punish grandchildren if not appeased, usually libation and powering of beer at their graves can stop problems caused by them.

${ }^{25}$ Kifaru = Spirit believed to be from Swahili people, Mayembe = Spirit from Buganda in central Uganda, Binego = spirit from Banyarwanda and Barundi: these are believed to be having power over life and for giving fortune.
} 
disease and related social issues. Baguma (THETA, 2015), adds that steps should be taken to understand the conditions that facilitate the emergence of healers, the type of clients attracted to these services, and the costs and benefits of traditional medicine, with the ultimate goal of involving indigenous African healers' education, and counselling programs.

\subsubsection{Rain-Making}

The researcher investigated rain making/okuhigaenzura and it was found out that these are rare but do exist. Rain makers are usually contacted to stop rain from spoiling ceremonies like funeral and wedding parties. It is believed that they have power to move the clouds and winds to take away the incoming or threatening rain: failure to pay heed to their instructions.

One of the rain maker said:

“...I am given entrails/all body parts of the slaughtered animal (offals $=$ eby'omunda $\left.{ }^{26}\right)$, roast and eat them, do not wash with any water till the end of the party....I keep enchanting my spirits and perform rituals (roasting pawpaw) that have the powers to stop rain.... if they do not follow my instructions, a storm will come and spoil the ceremony...."(Field interview, November, 2015).

Findings shows that rain making were a form of African traditional knowledge where the practitioner use powers that are not visible which stop rain. It was argued that the rains obey the commands of the rain-maker and drift away from the place if all the instructions s/he gives are obeyed and failure will make storms happen at the venue of the ceremony. However, when asked why these rain makers do not make rain fall during drought periods, they were hesitant to give answers. Further questioning on the possibility of failing to control the coming rain or ' rain over-powering' them, they said that it would happen if the process is tampered with especially when the rain maker accidently touches water or somebody makes him or her annoyed.

The rain making exercise could not be witnessed but the rain makers said that they belonged to a clan known as abaizib'enzura. Fetishes and horns of antelopes and male sheep were filled with herbs and such ingredients as they considered for the purpose. When people wanted rain, they took a black sheep to the rain maker, killed it and blood was allowed to flow in the fetish. The rain maker built a shrine where he put the fetish and had to abstain from sex until the rain came. Gifts of cereals and animals were given but if s/he became angry he would bring not only rain but hail-storms and thunder.

Rosce (1923) supports the finds of this study, he says that the rain makers bundle dried and rotten ekiikoplant twigs, pieces of trees, leaves of pineapples and earth (soil from the cooking place) tied on the reed fastened to a post planted in the ground in some secluded spot. Another stick to which a tied meat is put in a sloping position against this spot and under it fire is lit. S/he says, 'I want sun so that my fire may burn and cook the meat, let there be rain to extinguish it'. If $\mathrm{s} / \mathrm{he}$ is not paid this brings drought and famine.

Further arguments due to scholarship on pre-colonial healing in eastern Africa have concentrated on the nexus of causation binding therapeutic approaches to illness. Feierman (1992) argues that diagnoses are between two relatively stable categories: illnesses of God and illnesses of people. Illnesses of God just happen, but illnesses of people are caused by human action, especially the vengeful and antisocial actions of people labelled "sorcerers" or "witches." For example, people often explained droughts as the work of an enemy; "in a sense," a drought is "an illness of humanity raised to a public level." Yet, not all droughts are understood in this way. Some just happen, especially those which exceeded the territorial reach of a given healer. Illnesses of people precipitated actions involving "counter-sorcery" by a rainmaker greater than the one creating the illness. By this causal logic, people approach rainmaking through trial and error rather than through a differential diagnosis.

\subsubsection{Snake Poison Curing/Healing}

The study also investigated snake poison healing. It was found out that snake poison healers are very few (the study was able to get only two) but the healing knowledge was said to be in existence according to the data got from the respondents. The indigenous African healer said:

${ }^{26}$ Eby'omunda: Entrails (intestines, liver, kidneys etc) of the slaughtered animal 
“....once one bitten by a snake, the healer ties the belt just at the upper side of the place of the snake bite to stop poison from spreading to other parts, s/he touches the 'wound' or place of bite and removes the snake teeth and poison, use fire to remove the poison and rubs or smears herbs..."(Field interview, November, 2015).

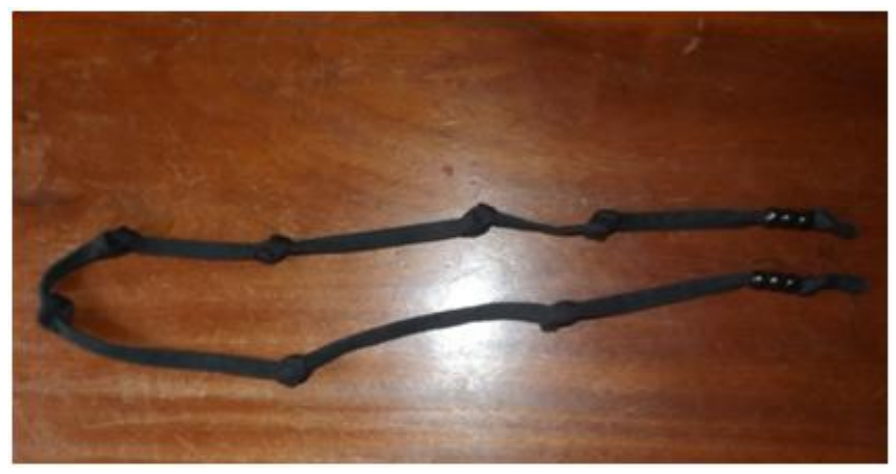

Plate1.6. Cloth Belt (Omweko) for curing snake poison

Source: Cloth belt/Omweko for snake poison treatment by an African Traditional Healer in Katete, Nyamitanga Division, Mbarara Municipality, Uganda (Field data, 2015)

Several explanations are possible for the outcome of this study: Ovugaet al., (1999) found, that Ugandan as well as Nigerian healers were confident in their ability to deal with human ailments and disorders. The confidence of African traditional healers is based on their cultural meaningful approach. Press (1982) notes that cultural healing and disease are characteristic of all human episodes of sickness: the relationship between traditional African healers and clients works much better when both have similar concepts of disease and patients are confident in their healers based on the "healthseeking' as a conditioned behaviour (Berry, 2004).

It was noted in the field that most patients receive a short time treatment and there is no follow up. Thus, the researcher does not know if the recovering is permanent or not. Compared with previous studies (Ovugaet al., 1999), the genuine African indigenous healers in Mbarara Municipality sent patients for conditions they could not cure (HIV/ AIDS, cancer) to medical doctors. This shows that educational workshops like those of THETA and NCTHHAinvolving healers have proven to successfully diffuse information regarding HIV/AIDS to communities in culturally meaningful ways. Thus patients with cancer or HIV were sent to medical doctors and the healers of NCTHHA only treated the non-clinical aspects of the disease. Sekagya (2006) argues that patients need medical treatment as well as a lot of psychosocial support and spirituality. Thus, it is very helpful to have programs like Bumetha Rukararwe in Southwest Uganda which combine the services of traditional healers with modern medical services in providing sustainable rural health care (Tumwesigye, et al., 1996).

\section{CONCLUSION}

The African philosophical clinical healthcare practice is the bridge between people's well-being and life. It is the practice that is embedded in the tradition, culture and taboos that are still relevant to the way of life of Africans. In order to maximize health care coverage there is a need for formalization of traditional health services through the integration of traditional medicine into health systems. This calls for enhanced collaboration between practitioners of conventional medicine and African indigenous medicine and healing for the benefit of the people

\section{REFERENCES}

[1] Awofeso N (2005): In: Re-defining 'Health'. Article: Üstün\&akob. 2005: 83:802 (Available at: http://www.who.int/ bulletin/bulletin_board/83/ustun11051/en/print.html, accessed on 1 June 2010)

[2] Berer, M. (2000): Safe Motherhood Initiatives: Reproductive Health Matters.

[3] Berry, D. (2004): Risk, communication and health psychology, McGraw-Hill International.

[4] Bodeker, G. (2005): Medicinal plant biodiversity and local healthcare - sustainable use and livelihood development. $17^{\text {th }}$ Commonwealth Forestry Conference. Colombo, Sri Lanka, 28 February-5 March 2005. Forestry Commission, Edinburgh, UK

[5] Bourdieu. P (1977): Outline of a Theory of Practice. R. Nice trans. Cambridge University Press 
[6] Coetzee (2001): Commercialization of South African Indigenous Crops: Aspects of Research and Cultivation of Products

[7] Coopoosamy, R.M. and Naidoo, K.K. (2011): Screening of traditional utilized Haworthialimifoliafor antibacterial and antifungal properties. Journal of Medicinal Plants Research 1

[8] Doornbos, M.R (1978): Not all the Kings' Men: Inequality as a Political Instrument in Ankole, Uganda. NewYork: Mouton Publishers

[9] Hauff, V. (2002): Sustainability Analysis: The Key to the Future. Deutschland Magazine 2

[10] Kurt Alan VerBeek (2000): Spirituality: a development taboo. Development in Practice, Volume 10, Number 1

[11] Magoro, M.D. (2008): Traditional health practitioners' practices and the sustainability of extinctionprone traditional medicinal plants.M.Sc. Dissertation. University of South Africa, Pretoria

[12] Mander, M., Ntuli, L., Diedericks, N. and Mavundla, K. (2007): South Africa's traditional medicines industry. Department of Trade and Industry, South Africa

[13] Mbiti, J (1989: African Religion and Philosophy, Oxford: Heinemenn Educational Publisher Oxford Ltd USA

[14] Mbiti, J (1978): Introduction to African Religion, London: Heinemenn

[15] Moeng, T.E. (2010): The impact of muthi shops and street vendors on medicinal plants of the Limpopo Province. M.Sc. Dissertation.University of Limpopo, Sovenga.

[16] National Council of traditional Healers and Herbalists Associations of Uganda (NACOTHA), http://www.blackherbals.com.nacothat1.htm (accessed 12 April 2014).

[17] Nelms .L. W and Gorski. J (2006): The Role of the African Traditional Healer in Women's Health. PubMed Commons

[18] Olanike F. D. (2011): Gender and Rural Development: Introduction

[19] Scheidegger P, Degonda M.(2008): Connecting: Die therapeutischeArbeit von traditionellen Heilern in Uganda. CH-Hypnose.

[20] Schoenbrun, D. L (2015): Conjuring the Modern in Africa: Durability and Rupture in Histories of Public Healing between the Great Lakes of East Africa

[21] Sekagya Y. (2006): Traditional healer's self-proficiency training in traditional medicine. Towards psychosocial support for HIV/AIDS patients and caregivers at prometra- uganda forest [Online].2006.

[22] The World Bank (2004): Indigenous Knowledge: Local Pathways to Global Development, 'Marking Five Years of the World Bank Indigenous Knowledge for Development Program'

[23] THETA (2001): Contributions of traditional medicines to health care delivery in Uganda. Ministry of Health Public-Private Partnership Office

[24] THETA (2015): Contributions of traditional medicine to health care deliveries in Uganda. Kampala: Ministry of Health, Public and Private Partnership Office

[25] Truter, I. (2007): African traditional healers: Cultural and religious beliefs intertwined in a holistic way. South African Pharmaceutical Journal 8

[26] Tumwesigye O. BumethaRukararwe (1996): Integrating Modern and Traditional Health Care in Southwest Uganda. The Journal of Alternative and Complementary Medicine, 1996; 2(3): 373-376.

Citation: Dr. Barigye Godfrey. "African Indigenous Medicine Activities in Mbarara Municipality, Uganda" International Journal of Research in Sociology and Anthropology (IJRSA), vol 5, no. 1, 2019, pp. 45-63. doi:http://dx.doi.org/ 10.20431/2454-8677.0501006.

Copyright: (C) 2019 Authors. This is an open-access article distributed under the terms of the Creative Commons Attribution License, which permits unrestricted use, distribution, and reproduction in any medium, provided the original author and source are credited. 